\title{
Editorial
}

\section{Material Flow Cost Accounting - looking back and ahead}

\section{Keywords}

Material Flow Cost Accounting

Input/output-balance

Process flow charts

Environmental management accounting

Eco-efficiency

Resource efficiency

\begin{abstract}
A B S T R A C T
Material Flow Cost Accounting (MFCA) combines physical flows and monetary units and is located between energy and material efficiency analyses, environmental management and managerial accounting procedures. Since the development of ISO 14051:2011 research and application in industry increased, but still some theoretical, methodological and practical gaps exist. This Special Volume addresses some of the existing deficits and shows the fertile contribution of MFCA on resource efficiency. As can been seen by the articles and case studies in this Special Volume, MFCA still is continuously spreading into further countries and the methodology is extended, refined and elaborated and increasingly applied in combination with various other tools and concepts. The main challenges are still the continuous implementation of the method in industry and the public dissemination of the results.
\end{abstract}

\section{Material flow thinking can shape managerial thinking}

To cope with complexity the perception of corporate reality is reduced by narrowing the focus of perception, resulting in limited attention (Simons, 1995). Engineers see the functioning of technical processes and products. Managers see the cost and profit side. Environmental officers see emissions, effluents and waste. All three tend to improve the corporate reality they see. This does not necessarily lead to an overall optimization of corporate goals as conflicts occur. Technical improvements focus in the first instance on the technical functioning, and might neglect costs and environmental aspects. Cost saving procedures might lead to staff reduction, not considering that this might produce new environmental burdens. Environmental considerations might request a new product design (e.g. of decomposability), leading to conflicts with production engineers etc.

By showing the common denominator of the various perceptions and foci, material flow thinking supports the integration of the various views: Engineers might become more aware of environmental consequences. Environmental officers get better information on cost effects. In addition, management might get a better overview of all, technical, monetary and environmental aspects. Material Flow Cost Accounting (MFCA) as a tool for implementing material flow thinking can considerably enhance an integrated optimization.

This Special Volume offers a first comprehensive overview over roots, conceptual characteristics, recent and future developments of MFCA and governmental initiatives. MFCA has not yet been explored in depth in research literature. MFCA so far has been subject more to practical application and less to empirical coverage. The method is being used in many companies, especially in Japan and Germany, but also in low-income countries. Some of these more recent applications are documented in this Special Volume. However, for reasons of competition and confidentiality many companies hesitate to publish detailed information on material flows, on efficiency achievements and saving results. Nevertheless specific and new internally reported data and information on material flows are an important lever for more efficiently structuring material flows in a company and also making a contribution to "cleaner production". Thus, MFCA is not only a corporate accounting exercise but also belongs to the method toolbox of industrial ecology, as it chiefly addresses the efficient and effective use of natural resources. Its scope recently is being extended to the supply chain as well as to an even further reaching Life Cycle perspective. $^{5}$

MFCA essentially addresses the monetary relevance of physical material flows and losses for companies. It demonstrates physical and monetary quantities of material flows as two sides of the same coin. By quantifying physical material flows it not only provides a basis for technical analysis, but also for an environmental assessment. It quantifies the material going into the product, into air, into water or into soil, but it also traces indicators like material efficiency, toxicity, criticality etc.. And finally it also contributes to economic optimization as all flows are monetarily assessed.

\footnotetext{
5 See e.g. the recent development of a new ISO-Standard 14052 on MFCA in the supply chain still in progress or the proceedings linking MFCA to the concept of Life Cycle Assessment in the Abstract Book of the 11th International Conference on EcoBalance by The Institute of Life Cycle Assessment, Japan: http://ilcaj.sntt.or.jp/ EcoBalance2014/program/scientific_program.html.
} 
Thus the method is used to analyse the physical energy and material flows ${ }^{6}$ in production systems and then to assess them in monetary terms. Thinking in material flow systems enables the tracing of inefficient material and energy use, both from an economic and ecological perspective. Waste reduction becomes a major opportunity and objective. The assessment of an input-/output-mass balance of physical material flows is the starting point for several tools related to environmental management and cleaner production (emissions control, resource efficiency). In essence, all material input flows including energy and water are distinguished into product output and non-product output. Non-product output is evaluated not only with its disposal, treatment, and recycling costs, but the wasted material's purchase value, as well as handling and storage costs are included in the production costs of non-product value and disclosed in the management control system. At the same time, this full costs overview also can establish the baseline for an idealized zero waste scenario. Ideally, in a resource efficient production system, all inputs would be converted into products. MFCA is located at the interface between energy and material efficiency analyses, environmental management and managerial accounting procedures. Above all, the method points out opportunities for action that are economically advantageous from the point of view of companies, and at the same time, by saving resources, emissions, waste etc. are also environmentally expedient.

By this MFCA adopts a different perspective to many other environmental management and accounting tools. Savings in energy and material do not only lead to cost reductions, but are generally also environmentally advantageous. MFCA reveals material efficiency and cost saving opportunities regarding the wide range of raw and auxiliary materials and energies. And it also comprises all flows and storages along the value chain between input (purchase), throughput (production) and output (delivery or disposal). Thus MFCA can help to identify economically attractive materials that have so far slipped through the net of conventional economic assessment or cost accounting. It can help to prioritize the economically and environmentally most attractive starting points. And it supports a holistic view comprising the entire flow of materials throughout the company from $R \& D$ and product design to recycling and reuse, not only optimizing from a narrow functional or departmental point of view. In this way MFCA expands the options for action in companies that have so far been defined by narrow accounting and management control procedures. It should thus be seen as an instrument for management control purposes and be applied on a regular level, integrated with existing accounting, management control, planning, reporting, and production information systems.

Meanwhile the procedure is well documented in an international standard that enhances the understandability and the reception of the method: The ISO 14051 standard describes the "general framework" of the MFCA approach. A second standard, ISO 14052. that addresses "guidance for practical implementation in a supply chain" is currently being developed.

Nevertheless, even if MFCA is accompanied by scientific support or extended to scopes across the company boundaries it expresses the results in simple physical and monetary quantities that can be easily understood.

In this editorial we identify research gaps for MFCA-related topics and give an overview on the papers of this special volume.

\footnotetext{
${ }^{6}$ Energy flows as long as they are of material substance (oil, gas, wood, coal etc.) can be treated as other material flows and quantified in mass values $\left(\mathrm{kg}, \mathrm{m}^{3}\right)$. Electricity or heat flows with negligible or no masses in MFCA are considered separately or parallel in kWh or kcal.
}

\section{Research gaps}

As early as 1959, the German economist Paul Riebel already pointed out that conventional cost-accounting in companies aims to fulfil a number of different purposes, for instance costefficiency comparisons, price policy, or current profit and loss statement (Riebel, 1990, 1994). He inferred from this that first of all a purpose-neutral accounting database is necessary, on which various evaluation calculations with different objectives or purposes could then build. Based on physical quantities it should be possible to produce information for decision-relevant events between the company and the market as well as for those within the company. Viewed in this way, MFCA also serves a specific purpose, namely in the first instance to provide a purpose-free information basis describing present material flows (stocks and movements) in physical and monetary terms as the core of business. If this material based accounting system is available, a wide range of reports, evaluations, and calculations can be derived for various purposes, for purchasing, for production planning, for product design, for quality management, for investment decisions, up to environmental management evaluations. This would then even result in a natural bridge between an economic and environmental assessment of the same system. This common information basis could show material inefficiencies in physical quantities and value these inefficiencies in monetary terms. The results can be transferred into the profit and loss statement on the one hand, as well as into a company's environmental report on the other. The two sides of one coin could target for special analyses of efficiency potentials. What costs could be saved by avoiding inefficiencies? Or alternatively, what environmental pollution could be saved by this?

It is important to campaign for such a basic accounting system in companies. This alone allows the holistic assessments of production that are becoming increasingly significant in times of climate change and scarcity of resources. Companies must recognise that this leads to additional benefits which conventional accounting systems do not offer. MFCA is a strong argument here, as it calculates in monetary units. However, it should not be forgotten that MFCA at the same time is also a toolbox for sustainability and resource efficiency and that there is also a need for other, nonmonetary evaluation views.

Separation into material basic accounting and specific assessments, such as Carbon Footprint, can above all supply key performance indicators that are necessary for efficient and environmental steering of a company. The challenge in closing the efficiency gap is not to reveal potentials in a one-off exercise, but instead to continuously improve and above all implement findings in management action and operational routine. Experience from the lean production movement shows that the challenge lies not only in "hard" technical issues but quite often in "soft policies" (Rother, 2010; Schmidt, 2013). How can constant awareness for improving effectiveness and efficiency be created among management and in each individual member of the workforce? This is a question of leadership, but it has to be supported and accompanied by the constant supply of data and performance indicators. Peter Drucker expressed this succinctly: "If you can't measure it, you can't manage it." The inefficiencies must therefore be continuously tracked down and quantified. The MFCA approach is one technique for this aim.

The reference to lean production should be taken seriously as well. Lean production originated in the Toyota Production System (Ōno, 1988) and addresses efficiency and waste in production. Today there is hardly any automobile manufacturing company that does not work in accordance with these principles. But they do not consider energy and material wasting as wastage of value creation, faulty products, working time and scarce and costly 
resources. They do not cross-functionally consider the entire material flow between input and output, from $R \& D$ to waste management, in both, physical and monetary terms, in cost and environmental accounting terms, even if Muda, the Japanese word for waste, plays a key role. Accordingly it is not surprising that although MFCA as a method was developed in Germany, its importance was recognised above all in Japan. Kaizen and the Toyota Production System have prepared the field here. MFCA is the logical continuation of this efficiency approach of lean production with a double focus on both, the reduction of cost and of environmental burdens. At the same time the method also offers major opportunities for learning from the long-standing and very practice-driven experiences of lean production. One important task was always to implement such analysing and problemsolving systems sustainably in corporate management. The question of how important analysis instruments and continuous data provision are, as well as questions of leadership and staff training have already been answered here and tested in practice. In this connection MFCA could also learn about dissemination and successful implementation in companies. This could result in a highly interesting field of activity helping to increase resource efficiency in production.

Even if an ISO standard has been released in 2011 and a second will follow expanding the supply chain perspectives, not all topics have been covered already in the academic discussion. We analysed which topics covered in the ISO 14051 have been covered already and which still give room for further research (Table 1):

The status quo demonstrates that part of the research is already well elaborated, whereas there is still much room left for further studies. First of all, links to financial and management accounting systems need to be strengthened. In general accounting data constitute of physical quantities and monetary values, but often accounting focuses on the monetary perspective only. MFCA can draw the attention on the natural capital perspective and thus follow the idea of integrated reporting (IIRC, 2013). The challenge is to formulate statements in a way that both communities are interested in a topic and open their mind and combine disciplines.

Further, allocation mechanisms are lacking and thus cost allocation can be more elaborated in MFCA. In a first step, decent allocation within a company is important as only well allocated costs can be managed top-down. In a second step, cost allocation has to be addressed in the value chain. Similar challenges arise in the allocation of greenhouse gases (GHG) in the scope 3 level (GHGP, 2011) and in cost carryover between quantity centers. The integration of data with life cycle costing and supply chain management is essential as quality and success of management depend on this information (Agndal and Nilsson, 2009).

Originally, MFCA was developed to quantify non-product material flows. This includes internally and externally recycled materials and its associated costs. So far, this aspect is only developed in theory and practical concepts are still missing to a large extent. An integration of these concepts with accounting tools might be valuable to document and transfer costs of internally recycled material. This process has to be considered as value added and thus also calculated and reported (Günther, 2008).

The visualization of the general material flow model is already well understood and applied by different disciplines. In a next step the flow models have to be adapted to sector specific application in order to take into account the sector-specific relevance of the planetary boundaries (Rockström et al., 2009) and to involve all areas and install individual accounting methods.

Subsequently the management has to be involved in this process and results have to be published on international platforms to disseminate knowledge on integrated tools and practical application (Simons, 1995; IIRC, 2013).
Regarding the determination of necessary expertise silo thinking is dominating in MFCA research and practice. Integrated project teams in research and practice are an eminent way of conteracting this. In particular since environmental problems are increasing, sustainable solutions need an interdisciplinary base (Whiteman et al., 2013).

In order to avoid chaotic, arbitrary and not well-documented solutions, processes have to be organized from project base to permanent implementation. The regular implementation of methods leads not only in MFCA to standards and thus similar system boundaries and time frames but is a topic in most of the accounting methods. Increasing standardization fosters the comparability of results and thus the benefits of MFCA become more visible (Schäffer and Steiner, 2005).

Various processes, such as receiving, cleaning, cutting, mixing, assembling, heating, packing, inspecting and shipping, as well as material storage areas, can be considered as quantity centers. However, no link to existing information systems does exist. Not only management systems have to be integrated and linked, but also processes and information systems (Whiteman et al., 2013).

Further, the identification of inputs and outputs for each quantity center is discussed in many case studies, but little awareness is payed on the difference between raw and operating materials. A standardized assessment framework for input-output balance as proposed by Jasch (1999) or in other environmental assessment disciplines sets the boundaries between life cycle and process stages and thus improves the methodological quality of MFCA.

The quantification of material flows in monetary units is already well developed. However, there is potential for further research regarding the inclusion of external costs and the assignment of energy and system cost (Steffen et al., 2015). Further barriers in the context of MFCA do exist, mainly due to intransparent or lacking communication. Organizational change management is a promising approach to cope with the inherent barriers (Hueske and Guenther, 2015) and transfer theoretical knowledge on MFCA results into practice.

Linked to this issue and chapter 5.3.3 of the ISO standard is the general communication of MFCA results, which are often subject of confidentiality. Advancements of open book accounting (Kajueter and Kulmala, 2005) and the carryover between quantity centres would improve the process and push MFCA research on communication. Further identification and assessment of improvement opportunities are well developed and formulated in this special volume, in particular in the article of Christ and Burritt.

The road travelled can be summarized as follows: Having started from environmental management initiatives MFCA has further developed as environmental management has, too. Management accounting and control has always been reluctant towards the method, due to theoretical, but also practical reasons. This might be due to the focus on physical flows, the major difference to the traditional way of thinking of management accounting and control in monetary terms. MFCA will have a vibrant future, if challenges ahead will the tackled. We see issues to be handled in the integration with environmental management, management control systems, information systems and the supply chain. The question of project base or permanent use has to be answered for every company individually.

\section{Contribution of the special volume to fill the gap}

The look back and look ahead clarified the conceptual baselines of the MFCA approach as well as some terminology. It also showed the first regional implementation focus in Germany and Japan but also first spread outs to transitional countries. As can been seen 
Table 1

Past and future research and practical implementation of ISO 14051

\begin{tabular}{|c|c|c|c|c|}
\hline Chapter in ISO-standard & $\begin{array}{l}\text { Chapter ISO } \\
14051\end{array}$ & Looking back - well developed & $\begin{array}{l}\text { Topics covered in this } \\
\text { special volume }\end{array}$ & Looking ahead - research needed \\
\hline \multicolumn{5}{|c|}{ Fundamental elements of MFCA (ISO 14051, chapter 5) } \\
\hline Quantity center & 5.1 & Well-developed and implemented & Wagner & Links with financial and \\
\hline Material balance & 5.2 & Well-developed and implemented & Wagner & management accounting and \\
\hline Cost calculation & 5.3 & $\begin{array}{l}\text { Theoretically well-founded, but low } \\
\text { implementation level }\end{array}$ & Kokubu and Kitada & $\begin{array}{l}\text { control systems need to be } \\
\text { strengthened }\end{array}$ \\
\hline General & 5.3.1 & Not applicable & & \\
\hline Cost allocation & 5.3 .2 & Low application level & & Allocation mechanisms \\
\hline $\begin{array}{l}\text { Cost carryover between quantity } \\
\text { centers }\end{array}$ & 5.3 .3 & $\begin{array}{l}\text { Severe problems with existing } \\
\text { information systems }\end{array}$ & Bierer et al. & $\begin{array}{l}\text { Integration with life cycle costing } \\
\text { and supply chain management }\end{array}$ \\
\hline $\begin{array}{l}\text { Cost carryover of internally } \\
\text { recycled material }\end{array}$ & 5.3 .4 & Theoretically well-developed & & $\begin{array}{l}\text { Implementation assistance by } \\
\text { integration with accounting and } \\
\text { control tools }\end{array}$ \\
\hline Material flow model & 5.4 & $\begin{array}{l}\text { Visualization well understood and } \\
\text { applied by different disciplines }\end{array}$ & Jasch & Sector specific adaptation \\
\hline \multicolumn{5}{|c|}{ Implementation steps of MFCA (ISO 14051, chapter 6) } \\
\hline General & 6.1 & Not applicable & & \\
\hline Involvement of management & 6.2 & Little evidence in published papers & $\begin{array}{l}\text { Rieckhof et al.; } \\
\text { Kokubu and Kitada }\end{array}$ & $\begin{array}{l}\text { Knowledge dissemination on } \\
\text { integrated tools }\end{array}$ \\
\hline $\begin{array}{l}\text { Determination of necessary } \\
\text { expertise }\end{array}$ & 6.3 & Silo thinking & & $\begin{array}{l}\text { Integrated project teams in } \\
\text { research and practice }\end{array}$ \\
\hline $\begin{array}{l}\text { Specification of a boundary and a } \\
\text { time period }\end{array}$ & 6.4 & $\begin{array}{l}\text { Chaotic, arbitrary and not well- } \\
\text { documented }\end{array}$ & & $\begin{array}{l}\text { From project base to permanent } \\
\text { implementation }\end{array}$ \\
\hline Determination of quantity centers & 6.5 & $\begin{array}{l}\text { Several case studies, but little links } \\
\text { with existing information systems }\end{array}$ & & Integrated information systems \\
\hline $\begin{array}{l}\text { Identification of inputs and outputs } \\
\text { for each quantity center }\end{array}$ & 6.6 & $\begin{array}{l}\text { Many case studies, but little } \\
\text { awareness on the difference }\end{array}$ & $\begin{array}{l}\text { Schmidt; } \\
\text { Kasemset; }\end{array}$ & \\
\hline & & $\begin{array}{l}\text { between raw and operating } \\
\text { materials }\end{array}$ & $\begin{array}{l}\text { Chompu-inwai et al.; } \\
\text { Sulong et al.; }\end{array}$ & $\begin{array}{l}\text { Standardized assessment } \\
\text { framework for input-output }\end{array}$ \\
\hline $\begin{array}{l}\text { Quantification of the material flows } \\
\text { in physical units }\end{array}$ & 6.7 & & $\begin{array}{l}\text { Schmidt; } \\
\text { Kasemset; } \\
\text { Chompu-inwai et al.; } \\
\text { Sulong et al.; }\end{array}$ & $\begin{array}{l}\text { Iramework for input-output } \\
\text { balance }\end{array}$ \\
\hline $\begin{array}{l}\text { Quantification of the material flows } \\
\text { in monetary units }\end{array}$ & 6.8 & $\begin{array}{l}\text { Material and waste costs well } \\
\text { developed }\end{array}$ & $\begin{array}{l}\text { Kasemset; } \\
\text { Chompu-inwai et al.; } \\
\text { Sulong et al.; }\end{array}$ & $\begin{array}{l}\text { Assignment of energy and system } \\
\text { cost, inclusion of external costs }\end{array}$ \\
\hline $\begin{array}{l}\text { MFCA data summary and } \\
\text { interpretation }\end{array}$ & 6.9 & $\begin{array}{l}\text { Theoretically well developed, but } \\
\text { low implementation level }\end{array}$ & & Implementation barriers \\
\hline Communication of MFCA results & 6.10 & Often subject of confidentiality & & $\begin{array}{l}\text { Advancement of open book } \\
\text { accounting }\end{array}$ \\
\hline $\begin{array}{l}\text { Identification and assessment of } \\
\text { improvement opportunities }\end{array}$ & 6.11 & $\begin{array}{l}\text { Well developed in combination } \\
\text { with cleaner production projects, } \\
\text { but difficult as a stand alone option }\end{array}$ & $\begin{array}{l}\text { Bierer et al.; } \\
\text { Nakajima et al.; } \\
\text { Schmidt et al.; } \\
\text { Christ and Burritt; } \\
\text { Jasch }\end{array}$ & Interdisciplinary assessment teams \\
\hline
\end{tabular}

by the papers and case studies in this special volume, MFCA still is continuously spreading into further countries and the methodology is extended, refined and elaborated and increasingly applied in combination with various other tools and concepts.

This special volume contains a number of very interesting papers that also elaborate on the topics presented above. We have put together a selection of methodological papers as well as case studies from different regions of the world.

The paper of Bernd Wagner (2015) gives an overview on the historical development of the method of MFCA and can be used for educational purposes, but also as inspiration for new methods that might emerge. Interestingly enough the idea arose from observing a gap between input and output measured in physical terms in a company. First, simple mass balances were established, that were refined continuously. Later material flows were traced throughout the company and indicators developed in order to be able to control continuous improvement. Finally the method was codified in an international standard.

The paper by Ramona Rieckhof, Anne Bergmann and Edeltraud Guenther (2015) confronts the corporate and management world with the challenges of sustainable development. It argues that conventional management thinking is not prepared to cope with these challenges. It also shows how MFCA might be able to support the establishment of links between short term operational management tools and medium or long term oriented strategic considerations that are able to accept the manifest challenges of sustainability with its issues of environmental protection and climate change. The paper thus focuses on the goal of encouraging corporate strategy to move towards more efficient and sustainable use of natural resources. It is based on an exceptionally extended analysis of recent literature, embracing 82 articles, not only covering the MFCA focus but also including most current management concepts of Management Control Systems (MCS) and Levers of Control (LOC). The authors point out that a resource-efficient strategy can only be achieved if corporations commit themselves to medium and long term targets of sustainability on a strategic level and transfer them down to all corporate levels using management control systems. Based on the broad literature review the authors examine possible links and contributions of MFCA to basic management tasks. This covers core questions of how to integrate MFCA into existing information and accounting systems, of how to enhance corresponding reporting systems referring to adequate indicators of performance measurement, of how to implement and communicate such an integrative flow management thinking corporate-wide, across various functional areas and departments etc. 
The paper by Katsuhiko Kokubu and Hirotsugu Kitada (2015) addresses implementation challenges for MFCA. The authors demonstrate that MFCA already overcomes typical shortcomings of classical environmental management that generally is perceived as being in opposition to profit targets. By increasing resource efficiency MFCA can contribute to cost saving and profitability. Kokubu and Kitada argue that in corporate daily life resistance to a regular and continuous implementation of MFCA can be observed due to conflicts with already existing management tools and approaches. The authors show e.g. that the alerted awareness of MFCA guided management specifically regarding material losses can conflict with the now prevailing management conceptions. The paper reports on case studies that have successfully managed to overcome such typical conflicts between MFCA and the traditional management perspective. It discusses for instance steps towards a more precise accountability of "losses", the successful introduction of Performance Reporting Meetings (Tanabe Seiyaku) or Work-place Centred Environmental Assurance Systems (Canon). And it describes the concept of a sustainability oriented or enlarged balance score card, all measures that support a corporate development to meet jointly the future economic and environmental challenges of sustainability.

As MFCA is progressing around the world it meets other management concepts, sometimes in conflict, sometimes in synergy. Several papers attempt to develop MFCA further in combination with such other management tools. They present road maps for the integration of MFCA with classical management tools or measures to overcome possible conflicts:

The team of Annett Bierer, Uwe Götze, Lilly Meynerts and Ronny Sygully (2015) developed a model for the integrated use of Life Cycle Costing (LCC) and Life Cycle Assessments (LCA) that applies MFCA as the link between the two methods. Both LCC as well as LCA open up the management focus beyond short-sited corporate views and limits. While the concept of Life Cycle Costing is traditionally reduced to a pure cost accounting approach and LCA on the other hand to a primarily environmental tool, MFCA might function as a link between the two. MFCA might link the two approaches, taking advantage of their particular excellence, from cradle to grave, by simultaneously controlling economic and environmental effects, challenges and opportunities.

The concepts of Supply Chain Management (SCM) and MFCA have a number of common features. Both are targeting the improvement of material flows in terms of efficiency, of cost and time. While SCM was set up to improve relationships across the corporate boarder to suppliers, MFCA at the beginning was reduced to a restricted internal inside-company view. While MFCA on the other hand emphasized environmental awareness, SCM traditionally tended to neglect sustainability considerations. Nakajima et al. show how the two concepts can be joined. They exemplify how timely requirements of controlling carbon emissions along the supply chain, a not only contemporary political, but also economic, environmental and social demand, can be met by introducing MFCA along the supply chain and into SCM. Requirements and challenges of promoting a Low Carbon Supply Chain are the focus of the questionnaire research performed by Michiyasu Nakajima, Asako Kimura and Bernd Wagner (2015). The results show that there are three prerequisites for introducing MFCA into the Supply Chain:

- environmental performance indicators as performance evaluation criteria in purchasing

- awareness of the concept and outcome of MFCA in the purchasing department

- inter-organizational information sharing between buyers and suppliers.
If these requirements are met, the authors put forward, both sides, buyers and suppliers, can profit, in terms of cost reduction as well of lower carbon emissions.

Mario Schmidt (2015) links his MFCA elaborations to increasing the transparency of production-related greenhouse gas emissions. This is done by an algorithm that transfers the representation of all in- and outgoing materials and energies into a common unit of $\mathrm{CO}_{2}$ equivalents. Physical flows are valued with corresponding greenhouse gas emissions in order to analyse what amount of emissions could be saved if the losses were avoided. This alone would be a sufficiently innovative contribution to the present conceptual MFCA discussions to justify a stand-alone article. But Schmidt, in the same paper offers a number of additional forward-looking and highly innovative contributions. He supports the valuing of monetary and environmental impacts of physical quantities by a mathematical refinement of the MFCA approach, which at the same time is apt to facilitate the crucial further development of software accompanying the transparency of material flows. In addition Schmidt shows how to handle so far in MFCA concepts neglected multi-product cases of extended complexity. And he demonstrates the treatment of recycling flows, to be found regularly in complex production processes, but not yet systematically taken into consideration within MFCA concept developments.

The contribution by Anja Schmidt, Uwe Götze and Ronny Sygulla (2015) in the first instance exhibits another interesting case study, an example from the aluminium industry. But this case study, by looking more closely and in detail into variations of corporate production circumstances, at the same time opens up a number of new methodological core questions and enrichments. Three research fields and suggested solutions can be considered as major contributions to the enhancement of management control systems regarding the sustainable use of resources and energies in industrial production: First Schmidt, Götze and Sygulla discuss the special role and handling of energies and energy flows within the MFCA methodology. Schmidt et al. elaborate solutions of how to recognize and assess the material or mass properties of energies, e.g. ending up as emissions (with mass quantities) after combustion. On the other hand they demonstrate how to treat, measure, and quantify the energetic qualities of producing work, heat, electricity, noise etc. Even though there are still further methodological research questions to be followed up on, this article offers considerable new insights on how to deal with energy flows, their physical and monetary properties in MFCA. Equally innovative seems the extension of MFCA methodology by opening up, besides the traditional cost oriented approach, an access to revenue oriented assessments. This aspect promises to facilitate further the awareness and acceptance of material efficiency endeavours by corporate management. Finally and thirdly the contribution of Schmidt et al. helps to overcome a so far in most MFCA applications observable restriction of scope to one period consideration, e.g. to one accounting year. The authors introduce an excellent equipment to include long term investment calculation, to the toolbox of dynamic investment appraisals.

The paper of Stefan Schaltegger and Dimitar Zvezdov (2015) framed MFCA and environmental management accounting (EMA) literature into past and future oriented, as well as short and long term focus. This could provide application of the methods for a larger range of decision situations. The paper provides a research agenda for developing MFCA tools and spreading them to new areas.

No special volume would be complete without documented case studies. We have compiled a study by Chompoonoot Kasemset (2015) in the textile industry in Thailand, where the costs of Non Product output were reduced from $16 \%$ of total production costs to $11 \%$. 
Another case study was performed by Rungchat Chompuinwai, Benyaporn Jaimjit and Papawarin Premsuriyanunt (2015) at a wood manufacturer in Thailand. By combining MFCA and the Design of Experiments Approach, they achieved a reduction in wood material losses in the cutting process from $69 \%$ of total wood materials used to $54 \%$. The five case studies by Farizah Sulong, Maliah Sulaiman and Mohd Alwi Norhayati (2015) in the Malaysian SME sector additionally applied the Diffusion of Innovation Theory to interpret hindrances and success factors.

Adding an extra-organizational perspective, the paper of Christine Jasch (2015) presents a governmental initiative, namely the UNIDO TEST approach. Based on the experience, that establishing an Input/Output balance is still a challenge especially in SMEs in developed and transitional countries, the presented UN-initiative reveals possibilities for the introduction of material flow thinking. The core of the approach is the introduction of a mass balance in order to foster continuous improvement, but also to avoid to complex systems in the beginning. The paper presents the main idea and experiences with the approach.

Finally, Katherine Leanne Christ and Roger Burritt (2015) outline an agenda for future research based on an extensive MFCA literature review. Concerns are raised about the absence of theorising behind MFCA and the lack of knowledge and application of the tool in practice. An agenda identifying promising avenues for research, the scope of application within companies and broadening of methods for investigation is then outlined. It provides a promising outlook for future application and research.

\section{References}

Agndal, H., Nilsson, U., 2009. Interorganizational cost management in the exchange process. Manag. Account. Res. 20, 85-101.

Bierer, A., Götze, U., Meynerts, L., Sygully, R., 2015. Integrating life cycle costing and life cycle assessment using extended material flow cost accounting. J. Clean. Prod. 108, 1289-1301.

Chompu-inwai, R., Jaimjit, B., Premsuriyanunt, P., 2015. A combination of Material Flow Cost Accounting and design of experiments techniques in an SME: the case of a wood products manufacturing company in northern Thailand. J. Clean. Prod. 108, 1352-1364.

Christ, K.L., Burritt, R.L., 2015. Material flow cost accounting: a review and agenda for future research. J. Clean. Prod. 108, 1378-1389.

GHGP, 2011. Corporate Value Chain (Scope 3) Accounting and Reporting Standard. In: Supplement to the GHG Protocol Corporate Accounting and Reporting Standard.

Günther, E., 2008. Ökologieorientiertes Management. UTB GmbH.

Hueske, A.K., Guenther, E., 2015. What hampers innovation? External stakeholders, the organization, groups and individuals: a systematic review of empirical barrier research. Manag. Rev. Q. 65, 113-148.

IIRC, 2013. The International IR Framework.

ISO, 2012. ISO 14051, Environmental Management - Material Flow Cost Accounting. General Framework.

ISO, 2015. ISO 14052, Environmental Management - Material Flow Cost Accounting Guidance for Practical Implementation in a Supply Chain (Committee Draft).

Jasch, C., 2015. Governmental Initiatives: The UNIDO TEST approach. J. Clean. Prod. $108,1375-1377$

Jasch, C., 1999. Ecobalancing in Austria: its use in SMEs and for benchmarking. In: Benett, M., James, P., Klinkers, L. (Eds.), Sustainable Measures: Evaluation and Reporting of Environmental and Social Performance, vol. 151, No. 169. Greenleaf Publishing in association with GSE Research, pp. 151-169.

Kajueter, P., Kulmala, H.I., 2005. Open-book accounting in networks: potential achievements and reasons for failures. Manag. Account. Res. 16, 179-204.

Kasemset, C., 2015. Application of MFCA in waste reduction: case study on a small textile factory in Thailand. J. Clean. Prod. 108, 1342-1351.

Kokubu, K., Kitada, H., 2015. Material Flow Cost Accounting and Existing Management Perspectives. J. Clean. Prod. 108, 1279-1288.

Nakajima, M., Kimura, A., Wagner, B., 2015. Introduction of MFCA to the supply chain: a questionnaire study on the challenges of constructing a low-carbon supply chain to promote resource efficiency. J. Clean. Prod. 108, 1302-1309.

Ōno, T., 1988. Toyota Production System: beyond Large-scale Production. Productivity Press.

Riebel, P., 1990. Einzelkosten- und Deckungsbeitragsrechnung/Grundfragen einer markt- und entscheidungsorientierten Unternehmensrechnung.

Riebel, P., 1994. Core features of the 'Einzelkosten-und Deckungsbeitragsrechnung' Eur. Account. Rev. 3, 515-546.
Rieckhof, R., Bergmann, A., Guenther, E., 2015. Interrelating material flow cost accounting with management control systems to introduce resource efficiency into strategy. J. Clean. Prod. 108, 1262-1278.

Rockström, J., Steffen, W., Noone, K., Persson, Å., Chapin III, F.S., Lambin, E.F., Lenton, T.M., Scheffer, M., Folke, C., Schellnhuber, H.J., Nykvist, B., de Wit, C.A., Hughes, T., van der Leeuw, S., Rodhe, H., Sörlin, S., Snyder, P.K., Costanza, R., Svedin, U., Falkenmark, M., Karlberg, L.R., Corell, W., Fabry, V.J., Hansen, J., Walker, B., Liverman, D., Richardson, K., Crutzen, P., Foley, J.A., 2009. A safe operating space for humanity. Nature $461,472-475$.

Rother, M., 2010. Toyota kata: Managing People for Improvement, Adaptiveness, and Superior Results. McGraw Hill, New York, NY.

Schäffer, U., Steiner, D., 2005. Wie nutzen Geschäftsführer und Vorstände in deutschen Industrieunternehmen ihre Kostenrechnung? Controlling 17, 321-325.

Schaltegger, S., Zvezdov, D., 2015. Expanding material flow cost accounting. Framework, review and potentials. J. Clean. Prod. 108, 1333-1341.

Schmidt, A., Götze, U., Sygulla, R., 2015. Extending the scope of Material Flow Cost Accounting - methodical refinements and use case. J. Clean. Prod. 108 $1320-1332$

Schmidt, M., 2015. The interpretation and extension of MFCA in the context of environmental material flow analysis. J. Clean. Prod. 108, 1310-1319.

Schmidt, M., 2013. Was haben Ressourceneffizienz und Lean Production gemeinsam? In: Klinke, S, Rohn, $H$. (Eds.), RessourcenKultur: Vertrauenskulturen und Innovationen für Ressourceneffizienz im Spannungsfeld normativer Orientierung. Nomos-Verlag Baden-Baden, pp. 279-294.

Simons, R., 1995. Levers of Control: How Managers use Innovative Control Systems to Drive Strategic Renewal. Harvard Business Press, Boston, MA.

Steffen, W., Richardson, K., Rockström, J., Cornell, S.E., Fetzer, I., Bennett, E.M., Carpenter, S.R., de Vries, W., de Wit, C.A., Folke, C., Gerten, D., Heinke, J., Mace, G.M., Persson, L.M., Ramanathan, V., Reyers, B., Sörlin, S., 2015. Planetary boundaries: guiding human development on a changing planet. Science 347 (6223), 1259855

Sulong, F., Sulaiman, M., Norhayati, M.A., 2015. Material Flow Cost Accounting (MFCA) enablers and barriers: the case of a Malaysian small and mediumsized enterprise (SME). J. Clean. Prod. 108, 1365-1374.

Wagner, B., 2015. A report on the origins of MFCA research activities. J. Clean. Prod. $108,1255-1261$.

Whiteman, G., Walker, B., Perego, P., 2013. Planetary boundaries: ecological foundations for corporate sustainability. J. Manag. Stud. 50, 307-336.

Edeltraud Guenther*

Technische Universitaet Dresden, Faculty of Business and Economics, Chair of Business Administration esp., Environmental Management and Accounting, Muenchner Platz 1/3, D-01187 Dresden, Germany

Christine Jasch ${ }^{1}$

Institute for Environmental Management and Economics, Christine Jasch, Rechte Wienzeile 19/10, A-1040 Vienna, Austria E-mail address: jasch.christine@ioew.at.

Mario Schmidt ${ }^{2}$

Institute for Industrial Ecology, Pforzheim University, Tiefenbronner Str. 65, D-75175 Pforzheim, Germany E-mail address: mario.schmidt@hs-pforzheim.de.

Bernd Wagner ${ }^{3}$

Environmental Science Center (WZU), Universitaet Augsburg, Universitaetsstr. 1a, D-86159 Augsburg, Germany E-mail address: wagner@wzu.uni-augsburg.de.

Patrick $\mathrm{Ilg}^{4}$

Technische Universitaet Dresden, Faculty of Business and Economics, Chair of Business Administration esp., Environmental Management and Accounting, Muenchner Platz 1/3, D-01187 Dresden, Germany E-mail address: patrick.ilg@tu-dresden.de.

${ }^{*}$ Corresponding author. Tel.: +49 35146332833.

E-mail address: ema@mailbox.tu-dresden.de (E. Guenther).

Available online 16 October 2015

\footnotetext{
1 Tel.: +43 664600031334

2 Tel.: +497231286406.

3 Tel.: +49 821598 3561, +49 82537000 .

4 Tel.: +4935146334313.
} 